\title{
Effectiveness of Boiled Comfrey Leaves (Symphytum Officinale L) on SGOT SGPT Serum in Male Wistar Strain Rats With Acute Hepatitis Models
}

\author{
Rois Sahidin ${ }^{1}$, Untung Sudhamono ${ }^{2}$ \\ Faculty of Nursing, Adventist University, Bandung \\ sahidinrois@gmail.com
}

\begin{abstract}
Acute hepatitis is an acute disease caused by viruses, alcohol and drugs, which is characterized by an increase in SGOT SGPT serum. The purpose of this study was to determine the effectiveness of boiled comfrey leaves (Symphytum Officinale L) levels of SGOT and SGPT serum in male wistar strain rats with acute hepatitis models. The objects in this study were 30 male Wistar strain rats aged 2-3 months with a weight of 180-200 grams. The objects were randomly divided into 3 groups: the treatment group, positive control and negative control. The treatment group and positive control group were induced paracetamol $120 \mathrm{mg}$ / day orally for 7 days. Boiled water of 2.8 grams of comfrey (symphytum officinale L) leaves was given as much as $2.7 \mathrm{cc}$ orally for 7 days to the treatment group. Data were analyzed with SPSS version 24, one way ANOVA test was performed to compare serum levels of SGOT \& SGPT. The results showed there were significant differences in serum levels of SGOT between the treatment group, positive control and negative control $(p<0.05)$ and there were significant differences in SGPT results between the treatment group and positive control group ( $\mathrm{p}<0.05)$ but there were no significant differences between the SGPT levels of the treatment group and the negative control group $(p=0.173)$. As Conclusion, boiled Comfrey leaf has an effect in decreasing serum SGOT \& SGPT in male wistar strain rats with acute hepatitis model.
\end{abstract}

Keywords: Paracetamol, SGOT, SGPT, Symphytum Officinale L.

\section{INTRODUCTION}

Indonesia is one country that has a wealth of herbs that can be proud of. Indonesian medicinal plants are around 30,000 species. By having this wealth, Indonesia has the potential to develop herbal products with the similar quality with modern medicine. However, the natural resources in Indonesia have not been optimally utilized for the benefit of the community. only about 1,200 species of medicinal plants that are already in use rigorously as traditional herbal medicine. (Wa Ode Rustiah, 2014) .

The existence of plants as medicine has been well-known by Indonesian since ancient times which was inherited from generation to generation. Generally herbal remedy used to 
maintain health, prevent illness, cure disease, restore health of the body, as well as a cosmetic which is still done by the people of Indonesia who reached the era of millennial, which assumes having low side effects as well as low cost. One of the traditional herb plants is Comfrey ( Symphytum officinale L) from the Boraginaceae family. (Norma, Ulfa Triyani A.Latif, Syamsidar Usman, 2014).

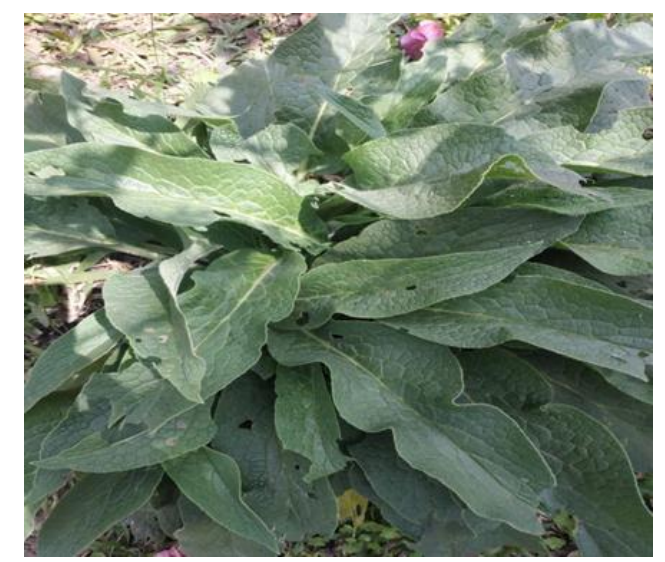

Figure 1. Comfrey Leaves

Comfrey ( Symphytum officinale L) is well known in Europe and West Asia, one of which is in Indonesia . Comfrey is found mostly in the tropics and grows in grassy and wet soil, making it easy to get. Green plants, with pseudo stems, single leaves, sharp edges and base, rough surface, about 27-50 cm long, 4.5-14 cm wide. Other names for komfrey are Symphytum Officinale L (Latin), "k’ang fu li” (Chinese), "knit bone" (English), "kompri", "gompfri", "kompering" (Java) (Jangga and Suriani, 2016).

Comfrey Leaves ( Symphytum Officinale L) has a slightly bitter taste and is cold. Chemicals contained in comfrey include symphytine, anadoline, pyrrolizdine alkaloids (pas), echimidine, essential oils, tannins, allatonin and vitamins (B1, B2, C and E). Comfrey leaves have anti-inflammatory and anti-rheumatic properties. (Diana, Yudyt, Wilson, 2016).

Comfrey leaf ( Symphytum Officinale L ) has been known as a medicine for various diseases, including hypertension, hypotension, diarrhea, ulcers, hemorrhoids, typhoid, appendicitis, bronchitis, pneumonia, lowering blood sugar, cancer, coughing up phlegm, tonsils, lowering blood cholesterol, tumors, fractures, kidney stones, hematuria, rheumatism, aching rheumatic pain and infertility in women. (Aserani Kurdi, 2010).

The liver is a complex organ that functions as a metabolism, regulation, and detoxification of foreign substances that enter the body. And if the liver is exposed to pathogens, drugs, alcohol, and toxins. As a result of liver cells become inflamed, which can reduce liver 
function so that the fatal risk to the body (Priscilla LeMone, Karen M. Burke, Gerene Bauldoff, 2017). The liver is one of the organs as a target of drugs, alcohol, and toxins. The accumulated use of drugs, alcohol, and toxins if entered into the liver and cannot be broken down and excreted and then stored in the liver will cause disruption of the liver cells / organelles. This can cause damage to the liver so that enzymes are free out of cells . (Widarti, Nurqaidah, 2019)

Hepatitis is a disease that is often found in the world including in Indonesia and hepatitis has been considered as a health problem in the community that must be quickly resolved. This is because there is a high prevalence, the hepatitis virus can also cause problems both acutely and chronically. $10 \%$ of hepatitis virus infections become chronic, $20 \%$ of chronic hepatitis sufferers within about 25 years from first contracting and will complications such as cirrhosis and hepatocellular carcinoma. (Risa Helilintar, Siti Rochana, Risky A Ramadhani, 2017). Hepatitis B virus has infected approximately 2 billion people in the world and around 240 million are people with chronic hepatitis B virus. The hepatitis $\mathrm{C}$ virus has infected approximately 170 million people and around 1,500,000 people worldwide die each year. Indonesia is one of the countries with the second largest number of hepatitis B after Myanmar among the member countries of WHO SEAR (South East Asian Region). Approximately 23 million people in Indonesia been infected by hepatitis B and 2 million people are infected by Hepatitis C. Hepatitis A is also often appears in the form of an outbreak (Outbreak) as happens in several places in Indonesia. According to the results of Riskesdas in 2007, the results of a Biomedical examination of 10,391 serum samples examined, the prevalence of HBsAg positive was $9.4 \%$, which means that among 10 inhabitants in Indonesia there is a person with Hepatitis B virus. At present in the world there are estimated to be around 350 million people with (carier) HBsAg and 220 million (78\%) of them are found in Asia, including Indonesia. (M. Yusuf Alamudi, M. Irfan Hadi, Mei Lina Fitri Kumalasari, 2018)

Paracetamol is a medicine that can be used to reduce fever and relieve pain, such as headaches and muscle aches. Paracetamol is safe for consumption when the therapeutic, but when consumed at high doses and estab a Kaian with long-term (overdose) will cause necrosis of liver cells in the area sentrolobuler which can lead to acute liver failure. During an overdose, the levels of glutathione-SH (GSH) in liver cells become greatly reduced which results in the susceptibility of liver cells to injury by oxidants and also allows N-acetyl-pbenzokuinone (NAPQI) to covalently bind the macromolecules of cells that cause dysfunction of various enzyme systems. The use of paracetamol with high doses and long 
periods of time can cause side effects, which include the effects of hepatotoxicity which can damage cells in the liver. One of the parameters of liver damage is the enzyme SGOT (Serum Glutamate Oxaloacetate Transaminase) and SGPT (Serum Glutamate Pyruvate Transaminase). ( Ita Dwi Rafita, Lisdiana, Aditya Marianti. 2015).

SGOT (Serum Glutamate Oxaloacetate Transaminase) and SGPT (Serum Glutamate Pyruvate Transaminase) enzymes are aminotransferase groups and as specific parameters of liver function damage. Damage to the cell membrane causes the enzyme Glutamate Oxaloacetate Transaminase (GOT) out of the cytoplasm of cells that have been damaged, and the amount will increase in the blood, so that it can be used as an indicator of damage to the liver. (Heru Sasongko, Sugiarto, 2018).

Serum Glutamate Oxaloacetate Transaminase (SGOT) or Aspartarte aminotransferase (AST) and Serum Glutamate Pyruvate Transaminase (SGPT) or Alanine aminotransferase (ALT) tests are needed for liver function to help in the diagnosis of doctors to patients, especially in patients with impaired liver function. Examination of liver function tests that are needed include specific tests on the inflammation of the liver parenchyma that is, aims to determine inflammation that occurs in the body and is usually an indication of interference or inflammation in the liver. (Ahmad Reza, Banundari Rachmawati, 2017).

The purpose of this study was to determine the effectiveness of boiled water of Komfrey D ( Symphytum Officinale L ) at a dose of $2.7 \mathrm{cc} /$ day orally for 7 days to reduce levels of SGOT (Serum Glutamate Oxaloacetate Transaminase) and SGPT (Serum Glutamate Pyruvate Transaminase) at 7 days against the reduction in levels of SGOT (Serum Glutamate Oxalacetate Transaminase) and SGPT (Serum Glutamate Pyruvate Transaminase) on Wistar strain male rats model paracetamol-induced hepatitis $120 \mathrm{mg} /$ day orally for 7 days . The results of this study are expected to provide scientific information to the public about the effects of the Komfrey Leaf ( Symphytum Officinale L ) decoction water to reduce levels of SGOT and SGPT.

\section{METHODS}

The object of the study were 30 male Wistar strain rats that were adapt for 7 days (12 hours dark and 12 hours light) and the mice were given food and drink normally, and regularly . Then the object was divided into 3 groups with each group consisting of 10 male Wistar rats, namely : group 1 (negative group, only given normal food and drink), group 2 (positive group, the liver was destroyed with paracetamol $120 \mathrm{mg} /$ day) and group 3 (treatment group, 
the liver was destroyed with paracetamol $120 \mathrm{mg} /$ day and given boiled water therapy 2.8 grams of comfrey leaves in $150 \mathrm{cc}$ of water and given as much as $2.7 \mathrm{cc}$ orally for 7 days).

After adaptation for 7 days (12 hours dark and 12 hours light). In 8th day to the 15 th day group 2 (positive control group) and group 3 (treatment control group) were the liver waer damaged by inducing paracetamol as much as $120 \mathrm{mg}$ orally for 7 days.

On the 15th day all groups were taken blood samples to check the levels of SGOT (Serum Glutamate Oxaloacetate Transaminase) and SGPT (Serum Glutamate Pyruvate Transaminase). as a result of the pre-test, and specifically group 3 (treatment control group ) were given treatment with boiled water of $2.8 \mathrm{gr}$ comfrey leaves ( Symphytum Officinale L ) in $150 \mathrm{cc}$ of water and given as much as $2.7 \mathrm{cc}$ orally for 7 days. On the 22 nd day all groups took blood samples for examining of SGOT and SGPT levels as a result of the post test and analyzed the results using the SPSS version 24, one way ANOVA test conducted to compare SGOT and SGPT levels in the liver

\section{RESULTS AND DISCUSSION}

SGOT (Serum Glutamate Oxaloacetate Transaminase) and SGPT (Serum Glutamate Pyruvate Transaminase) are enzymes of aminotransferase class and work as a specific parameters of liver function damage. Intra cellular enzymes that normally should be in cells. If there are toxic compounds in the liver, there will be a change in permeability in the cell membrane. So the enzymes that are supposed to be in the cell eventually come out and found in the blood. ( Safwan, Abdul R, Ali R. 2014).

In this study two measurements were taken in determining the levels of the SGOT (Serum Glutamate Oxaloacetate Transaminase) and SGPT (Serum Glutamate Pyruvate Transaminase) enzymes before getting a treatment with comfrey leaf decoction (Symphytum officinale L), and to find out the results of the levels of SGOT (Serum Glutamate Oxaloacetate Transaminase) and SGPT enzymes (Serum Glutamate Pyruvate Transaminase) after being given boiled water treatment for comfrey ( Symphytum Officinale L ) leaves.

Statistical test results using SPSS version 24, one way ANOVA test conducted to compare the results before and after the treatment of comfrey leaf (Symphytum Officinale L) decoction on levels of the SGOT (Serum Glutamic Oxaloacetate Transaminase) and SGPT (Serum Glutamate Pyruvate) transaminase) on Male wistar strain rats acute hepatitis model. The analysis results are as follows : 
Table 1. Comparison of the results of SGOT levels in the blood serum of male Wistar rats on the 15th day before the treatment of comfrey leaf decoction ( Symphytum Officinale $\mathbf{L}$ )

\begin{tabular}{|c|c|c|c|c|c|}
\hline $\begin{array}{l}\text { Dependent } \\
\text { Variable }\end{array}$ & (I) GROUPS & (J) GROUP & $\begin{array}{c}\text { Mean } \\
\text { Difference (IJ) }\end{array}$ & Std. Error & Sig. \\
\hline \multirow[t]{6}{*}{ SGOT_PRE } & \multirow[t]{2}{*}{1 (negative) } & 2 (positive) & $-226.92000^{*}$ & 13,46066 & .000 \\
\hline & & 3 (treatment) & $-198.41000^{*}$ & 13,46066 & .000 \\
\hline & \multirow[t]{2}{*}{2 (positive) } & 1 (negative) & $226,92000^{*}$ & 13,46066 & .000 \\
\hline & & 3 (treatment ) & 28.51000 & 13,46066 & .105 \\
\hline & \multirow[t]{2}{*}{3 (treatment) } & 1 (negative) & $198.41000^{*}$ & 13,46066 & .000 \\
\hline & & 2 (positive) & -28.51000 & 13,46066 & .105 \\
\hline
\end{tabular}

From table 1 above, it was found that SGOT (Serum Glutamate Oxalacetate Transaminase) levels of male wistar strain rats on day 15 before being given comfrey leaves (Symphytum Officinale L) decoction therapy as much as $2.7 \mathrm{cc}$ orally in male wistar strain rats that had been induced with paracetamol as much as $120 \mathrm{mg} /$ day for 7 days. The results obtained from above is that in group 1 (negative control group) compared with group 2 (positive control group) and group 3 (treatment control group) show a significant results $(p<0.05)$, this happened because in group 2 ( positive control group ) and group 3 (treatment control group) the liver was equally destroyed by paracetamol-induced $120 \mathrm{mg} /$ day for 7 days orally, so that the levels of SGOT (Serum Glutamate Oxaloacetate Transaminase) in group 2 (positive control group) and group 3 (treatment control group) increased, whereas in group 1 (negative control group) the levels of SGOT ( Serum Glutamate Oxalacetate Transaminase) were normal. But in group 2 (positive control group) compared with group 3 (treatment control group) there was no significant difference $(\mathrm{p}=0.105)$, this was happen due to the induction effect of paracetamol as much as $120 \mathrm{mg}$ / day, orally for 7 days. In group 2 ( positive control group ) and group 3 (treatment control group) which can increase levels of SGOT ( Serum Glutamate Oxaloacetate Transaminase) in male wistar strain rats with an acute hepatitis model. The increase in SGOT ( Serum Glutamate Oxaloacetate Transaminase ) is caused by given paracetamol as a anti-pyretic analgesic drugs, when it is used in large doses or in a long time can cause an acute damage to the liver (hepatitis) with encephalopathy. This condition occurs due to the formation of toxic reactive metabolic and free radicals through the biotransformation process by the cytochrome P450 enzyme with the help of the CYP2E1 isoenzyme. Pharmacologically every drug ingredient including paracetamol that enters the 
body will undergo a pharmacodynamic and pharmacokinetic process. Paracetamol is consumed through absorption in the intestine, then distributed throughout the body to undergo metabolic processes in the liver and subsequently excreted. Liver cells become organs that have the potentially experiencing inflammation or damage due to toxic compounds. When the liver is damaged or inflamed, the SGOT enzyme (Serum Glutamate Oxaloacetate Transaminase) will be released into the bloodstream. So that when laboratory tests are performed the SGOT levels (Serum Glutamate Oxalacetate Transaminase) will be increased. (Sri Oktavia, Ifora, Suhatri, Marni Susanti, 2017).

Table 2. Comparison of the results of SGOT levels in the blood serum of male wistar rats on day 22 after treatment of leaf decoction of komfrey ( Symphytum Officinale $L$ )

\begin{tabular}{|l|l|l|l|l|l|}
\hline \multirow{4}{*}{$\begin{array}{c}\text { Dependent } \\
\text { Variable }\end{array}$} & (I) GROUPS & \multicolumn{1}{|c|}{$\begin{array}{c}\text { Mean } \\
\text { (J) GROUP }\end{array}$} & $\begin{array}{c}\text { Difference (IJ) } \\
\text { Std. Error }\end{array}$ & Sig. \\
\hline \multirow{4}{*}{ SGOT_POST } & 1 (negative) & 2 (Positive) & $-963.26000^{*}$ & 15.43255 & .000 \\
\cline { 3 - 6 } & & 3 (Treatment) & $-75.03000^{*}$ & 15.43255 & .000 \\
\cline { 2 - 6 } & 2 (Positive) & 1 (negative) & $963.26000^{*}$ & 15.43255 & .000 \\
\cline { 2 - 6 } & & 3 (Treatment) & $888.23000^{*}$ & 15.43255 & .000 \\
\cline { 2 - 6 } & \multirow{2}{*}{3 (Treatment) } & 1 (negative) & $75.03000^{*}$ & 15.43255 & .000 \\
\cline { 3 - 6 } & & 2 (Positive) & $-888.23000^{*}$ & 15.43255 & .000 \\
\hline
\end{tabular}

From the table 2 above, it was found that the SGOT (Serum Glutamate Oxalacetate Transaminase) ratio after treatment of 2.8 grams of comfrey leaves (Symphytum Officinale L), which was given as much as $2.7 \mathrm{cc} /$ day orally within 7 days. So that in group 1 (negative control group) compared with group 2 (positive control group) and group 3 (treatment control group) shows significant results $(\mathrm{p}<0.05)$. this happen because in group 1 (group negative control) the rats were not induced by paracetamol, but only fed and watered normally, whereas in group 2 (group positive control) rats induced by paracetamol $120 \mathrm{mg} /$ day orally for 7 days, so SGOT levels in group 2 Wistar male rats (positive control group) increased after being induced by paracetamol $120 \mathrm{mg} /$ day orally for 7 days. And group 3 (treatment control group) rats were induced by paracetamol as much as $120 \mathrm{mg} /$ day orally for 7 days and had been given a therapy of 2.8 grams comfrey leaves (Symphytum Officinale L) decoction, which was given as much as $2.7 \mathrm{cc} /$ day orally in within 7 days, so the levels of SGOT in rats induced by paracetamo $1120 \mathrm{mg} /$ day orally for 7 days decreased. This is supported by the comparison between group 2 (positive control group) and group 3 (treatment control group) that shows a significant result $(\mathrm{p}<0.05)$. this situation happen 
because in group 3 (treatment control group) male Wistar strain rats have been given the therapy of comfrey leaves (Symphytum Officinale L) decoction, which is given as much as $2.7 \mathrm{cc} /$ day orally within 7 days. whereas in group 2 (positive control group) the rats were not given a water treatment of komfrey leaf (Symphytum Officinale L). This shows that the SGOT levels of male Wistar rats after being given water therapy of komfrey leaf decoction at a dose of $2.7 \mathrm{cc} /$ day orally for 7 days is approaching the normal rate .

\section{Table 3. Comparison of the results of SGP T levels in the blood serum of male Wistar rats on the 15th day before being given a decoction of comfrey leaf (Symphytum Officinale L) treatment}

\begin{tabular}{|c|c|c|c|c|c|}
\hline $\begin{array}{c}\text { Dependent } \\
\text { Variable }\end{array}$ & (I) GROUPS & (J) GROUP & $\begin{array}{c}\text { Mean } \\
\text { Difference (IJ) }\end{array}$ & Std. Error & Sig. \\
\hline \multirow[t]{6}{*}{ SGPT_PRE } & \multirow[t]{2}{*}{1 (negative) } & 2 (Positive) & $-83.17000^{*}$ & 10,34551 & .000 \\
\hline & & 3 (Treatment) & $-107.38000^{*}$ & 10,34551 & .000 \\
\hline & \multirow[t]{2}{*}{2 (Positive) } & 1 (negative) & $83.17000^{*}$ & 10,34551 & .000 \\
\hline & & 3 (Treatment) & -24.21000 & 10,34551 & .067 \\
\hline & \multirow[t]{2}{*}{3 (Treatment) } & 1 (negative) & $107.38000^{*}$ & 10,34551 & .000 \\
\hline & & 2 (Positive) & 24.21000 & 10,34551 & .067 \\
\hline
\end{tabular}

From table 3 above, it was found that SGPT (Serum Glutamate Pyruvate Transaminase) of Wistar strain male rats on day 15 before being given comfrey leaf decoction therapy (Symphytum Officinale L) as much as $2.7 \mathrm{cc}$ orally in male Wistar strain rats that were induced with paracetamol $120 \mathrm{mg}$ / day for 7 days showed that in group 1 (negative control group) were compared to group 2 (positive control group ) and group 3 (treatment control group) shows significant results $(\mathrm{p}<0.05)$. This happened because in group 2 (positive control group) and group 3 (treatment control group) the liver was equally destroyed by paracetamolinduced $120 \mathrm{mg}$ / day orally for 7 days, so the levels of SGP T (Serum Glutamate Pyruvate Transaminase) in group 2 (positive control group) and group 3 (treatment control group) increased, whereas in group 1 (negative control group) the levels of SGOT ( Serum Glutamate Oxalacetate Transaminase) were normal. But group 2 (positive control group) and group 3 (treatment control group) had insignificant difference ( $\mathrm{p}=0.067)$, this was due to the induction effect of paracetamol as much as $120 \mathrm{mg} /$ day, orally for 7 days, in group 2 (positive control group) and group 3 (treatment control group) liver damage due to paracetamol results from a metabolite of NAPQI ( $\mathrm{N}$-acetyl-pbenzoquinoneimine) which is very reactive. Under normal circumstances this reactive product quickly binds to the levels of 
gluthation in the liver, so it becomes a non-toxic material. However, $\backslash$ usually in the overdose case, or the use in a long period of time which causes the production of NAPQI gradually increase, and is not proportional to the levels of gluthathion, then NAPQI binds macromolecules with liver cells that cause liver cell nexrosis. When the liver is damaged or inflamed, the SGPT enzyme (Serum Glutamate Pyruvate Transaminase) will be released into the bloodstream. So that when laboratory tests were performed the SGP T (Serum Glutamate Pyruvate Transaminase) levels will increase ( Yusri Dianne Jurnalis, Yorva Sayoeti, Marlia Moriska , 2015).

Table 4. Comparison of the results of SGP T levels in the blood serum of male Wistar rats on day 22 after being given a decoction of komfrey ( symphytum officinale $L$ ) leaf decoction .

\begin{tabular}{|c|c|c|c|c|c|}
\hline $\begin{array}{c}\text { Dependent } \\
\text { Variable }\end{array}$ & (I) GROUPS & (J) GROUP & $\begin{array}{c}\text { Mean } \\
\text { Difference (IJ) }\end{array}$ & Std. Error & Sig. \\
\hline \multirow[t]{6}{*}{ SGPT_POST } & \multirow[t]{2}{*}{1 (negative) } & 2 (Positive) & $-986.37000^{*}$ & 17,95850 & .000 \\
\hline & & 3 (Treatment) & -33.19000 & 17,95850 & .173 \\
\hline & \multirow[t]{2}{*}{2 (Positive) } & 1 (negative) & $986.37000^{*}$ & 17,95850 & .000 \\
\hline & & 3 (Treatment) & $953.18000^{*}$ & 17,95850 & .000 \\
\hline & \multirow[t]{2}{*}{3 (Treatment) } & 1 (negative) & 33.19000 & 17,95850 & .173 \\
\hline & & 2 (Positive) & $-953.18000^{*}$ & 17,95850 & .000 \\
\hline
\end{tabular}

From table 4 above it is found that there is an SGPT (Serum Glutamate Pyruvate Transaminase) ratio after the treatment of 2.8 grams of comfrey leaves (Symphytum Officinale L), which is given as much as $2.7 \mathrm{cc} /$ day orally within 7 days. So that in group 1 (negative control group) compared with group 2 (positive control group) significant results were obtained $(\mathrm{p}<0.05)$. this is because in group 1 (negative control group) rats were only fed and drinking normally and not induced by paracetamol120mg / day for 7 days, whereas in group 2 (positive control group) rats were induced by paracetamol 120mg / day orally for 7 days, so the levels of SGPT (Serum Glutamate Pyruvate Transaminase) in male rats in group 2 Wistar strain (positive control group) increased. Moreover, group 1 (group negative control ) ans group 3 (control group treatment) obtain that are not significant ( $\mathrm{p}=0.173$ ). This shows that the water boiled 2.8 grams of komfrey leaves (Symphytum Officinale L ), which was given as much as $2.7 \mathrm{cc} /$ day orally within 7 days can reduce levels of SGPT in group 3 (treatment control group) in male wistar strain rats with hepatitis model Acute induced by paracetamol as much as $120 \mathrm{mg}$ / day orally for 7 days so that SGPT levels in the treatment 
group approached normal levels as in the negative control group that was not damaged by the liver and were only given food and drink. Then $\mathrm{h}$ acyl of comparison between group 3 (control group treatment) were compared with group 2 (group positive control ) showed that a significant $(\mathrm{P}<0.05)$ for group 3 (control group treatment ) male rats wistar strain induced by paracetamol $120 \mathrm{mg} /$ day orally for 7 days to raise levels of ALT in male rats wistar strain, then diberika $\mathrm{n}$ komfrey leaves boiled water therapy that is given about $2.7 \mathrm{cc} /$ day orally within 7 days can reduce levels of ALT group 3 (control group treatment) in Wistar strain male rats with an acute hepatitis model after the liver of the Wistar strain male rats was damaged. Therefore, from the data above it can be concluded that the liver were initially damaged by the effects of inducing paracetamol $120 \mathrm{mg} /$ day orally for 7 days has been treated with boiled water of comfrey leaves were given as much as $2.7 \mathrm{cc} /$ day orally within 7 days can lower SGPT levels. it was different from group 2 (positive control group) which was destroyed with paracetamol $120 \mathrm{mg} /$ day orally for 7 days but was not given water treatment of comfrey leaf decoction .

So the results of the analysis of this study found that there were significant differences in SGOT enzyme levels between the treatment group, the positive control group and the negative control group $(\mathrm{p}<0.05)$ and there were significant differences in the SGPT results between the treatment group and positive control group $(\mathrm{p}<0.05)$. there was no significant difference between SGPT levels in the treatment group and the negative control group $(\mathrm{p}=0.173)$.

In general, rats male Wistar strain were given 2.8 grams of water decoction of comfrey leaves (Symphytum officinale L) as much as $150 \mathrm{cc}$ of water and $2.7 \mathrm{cc}$ orally has and effect in decreasing the SGOT (Serum Glutamic Oxaloacetate transaminase) and SGPT (Serum Glutamate Pyruvate Transaminase) enzyme in male wistar rats with acute hepatitis model.

This shows that the water of Comfrey leaves (Symphytum Officinale L) decoction has antioxidant effect so that it functions to stabilize NAPQI reactive metabolites. The way of how the boiled water of Comfrey leaves (Symphytum Officinale L) as a non-enzymatic antioxidant works is by inhibiting the propagation of radicals peroxyl. The only one in the form of $\alpha$-tocopherol is to donate the phenolic hydrogen atom to the peroxyl radical compound to form a more stable hydroperoxide compound. The tocopheroxyl radicals that are left behind are quite stable, cannot initiate the formation of other radicals and if met with peroxyl compounds will form non-radical products . (Martha Ardiaria, 2017) 


\section{Conclusion}

The results of this study found that paracetamol with a dose of $120 \mathrm{mg}$ that orally administered for 7 days to male wistar strain rats could damage or interfere the liver function, so that the SGOT (Serum Glutamate Oxaloacetate Transaminase) and SGPT (Serum Glutamate Pyruvate Transaminase) serum were removed from the liver, so that the SGOT enzymes (Serum Glutamate Oxaloacetate Transaminase) and SGPT (Serum Glutamate Pyruvate Transaminase) were removed from the liver. liver cells and enter the bloodstream. So that the levels of SGOT and SGPT in the blood increase during the laboratory examination.

And the conclusion of this study can be seen that the water decoction of 2.8 grams of comfrey leaf ( Symphytum officinale L ) in $150 \mathrm{cc}$ of water and $2.7 \mathrm{cc}$ orally mouth show an effect in decreasing SGOT (Serum Glutamate Oxaloacetate transaminase) and SGPT (Serum Glutamate Pyruvate Transaminase) enzyme in male wistar strain rats in acute hepatitis level

\section{REFERENCES}

Alamudi Yusuf M, M.Irfan Hadi Irfan M, Kumalasari Fitri L.M. (2018). Hbsag Screening In Teenagers In Surabaya By Using Rapid Test Skrining Hbsag Pada Remaja Di Surabaya Dengan Menggunakan Rapid Test. Jurnal Kesehatan Masyarakat Volume 9 Nomor , ISSN (P) 2088-3536 ISSN (E) 2528-3375

González Nossa Lisseth Diana, Pérez Talero Verónica Yudyt, Núñez Rozo Elias Wilson. (2016). Determination Of Polyphenols And Antioxidant Activity of Polar Extracts of Comfrey (Symphytum Officinale L).

Helilintar Risa, Rochana Siti, Ramadhani A Risky. (2017).Perancangan Sistem Diagonosa Penyakit Hepatitis Menggunakan Metode Knn. Jurnal Ilmiah ILKOM 9(2). ISSN cetak 2087-1716 ISSN online 2548-7779.

Jangga dan Suriani. (2016). Effects Test Leaf Extract Kompri (Symphytum Officinale L.) On Lowering Blood Glucose Levels Mice (Mus Musculus). The National Journal Of Pharmacy. ISSN1829-9008

Jurnalis Dianne Yusri , Yorva Sayoeti Yorva, Moriska Marlia. (2015). Kelainan Hati akibat Penggunaan Antipiretik. JurnalKesehatan Andalas. http://jurnal.fk.unand.ac.id

Kurdi Aserani, (2010). Tanaman Herbal Indonesia. Hal 153-155 E-Book Jilid 1

LeMone Priscilla, Burke M Karen, (2017). Buku Ajar Keperawatan Medikal Bedah (Gangguan Gastrointestinal) edisi 5. Jakarta : Penerbit Buku Kedokteran. Hal 916917 
Norma, A.Latif Triyani Ulfa, Usman Syamsidar. (2014). Efek Hepatotoksisitas Ekstrak Etanol Herbal Kompri (SymphytumofficinaleL.) Terhadap Hewan Uji Kelinci (Oryctolaguscuniculus) Dengan Parameter SGOT dan SGPT. Jurnal Ilmiah Biologi, 2(1), 11-15. ISSN 2302-1616

Oktavia Sri, Ifora, Suhatri, Susanti Marni. (2017). Uji Aktivitas Hepatoprotektor Ekstrak Daun Sirih Hijau (Piper Betle Linn.) Terhadap Kerusakan Hati Yang Diinduksi Parasetamol. Jurnal Farmasi Higea, (9)2

Rafita D Ita, Lisdiana, Marianti Aditya. (2015). Pengaruh Ekstrak Kayu Manis Terhadap Gambaran Histopatologi Dan Kadar Sgot-Sgpt Hepar Tikus Yang Diinduksi Parasetamol. Unnes Journal of Life Science 4(1) ISSN 2252-6277

Reza Ahmad, Rachmawati Banundari. (2017).Perbedaan Kadar Sgot Dan Sgpt Antara Subyek Dengan Dan Tanpa Diabetes Mellitus. Jurnal Kedokteran Diponegoro, (6)2 Issn Online : 2540-8844

Rustiah Ode Wa. (2014). Isolasi Dan Identifikasi Senyawa Alkaloid Yang Terkandung Dalam Herba Komfrey (Symphytum Officinale L) Asal Tana Toraja. Jurnal Teknosains, (8)3.

Safwan, R Abdul, R Ali. (2014). Toksisitas Subakut Ekstrak Biji Pepaya (Carica Papaya L.) Terhadap Aktivitas Enzim Serum Glutamic Oxaloasetic Transminase (Sgot) Mencit (Mus Musculus) Secara In Vivo

Sasongko Heru, dan Sugiyarto. (2018). Pengaruh Pemberian Ekstrak Daun Karika (Vasconcellea pubescens A.DC.) Terhadap Nilai SGPT dan SGOT pada Tikus Jantan yang Diinduksi Parasetamol. Journal of Pharmaceutical Science and Clinical Research, 2018, 02, 70-75. DOI :10.20961/jpscr.v3i2.21796

Widarti, Nurqaida. (2019). Analisis Kadar Serum Glutamic Pyruvic Transaminase (SGPT) Dan Serum Glutamic Oxaloacetic Transaminase (SGOT) Pada Petani Yang Menggunakan Pestisida. Jurnal Media Analis Kesehatan, 10(1), Juni 2019 e-ISSN : 2621-9557 p-ISSN : 2087-1333. 